\title{
Strategi Bertahan di Masa Pandemi Covid-19
}

\author{
${ }^{1}$ Arga Teriyan, ${ }^{2 *}$ Denok Sunarsi, ${ }^{3}$ Sarwani, ${ }^{4}$ Putri Anggreni, ${ }^{5}$ Ni Wayan Suartini \\ 1.2.3Universitas Pamulang Tangerang Selatan, Banten, Indonesia \\ 4.5Universitas Mahendradatta, Denpasar, Bali, Indonesia \\ *denoksunarsi@unpam.ac.id
}

\begin{abstract}
Abstrak
Tujuan yang ingin dicapai dalam kegiatan ini adalah: Untuk mengetahui sejauhmana keberhasilan literasi digital advertising dalam meningkatkan inovasi Umkm Kerajinan Perak Sai Silver di Bali di masa yang akan datang. Metode pelaksanaan pengabdian kepada masyarakat ini diawali dengan melakukan peninjauan lapangan dan koordinasi dengan mitra. Metode kegiatan ini adalah mendatangi dan memberikan pelatihan dan diskusi. Hasil dari kegiatan ini adalah para pengerajin diharapkan mampu memahami pentingnya periklanan digital dengan memanfaatkan internet khususnya sosial media yang dapat diakses oleh lebih banyak konsumen dengan menggunakan internet pada umumnya dan sosial media pada khususnya. Selain itu diharapkan juga dapat membantu dan meningkatkan kesejahteraan dan inovasi dalam mengembangkan produk kerajinan perak.
\end{abstract}

Kata Kunci: UMKM, Sosial Media, Iklan

\begin{abstract}
The objectives to be achieved in this activity are: To find out the success of digital advertising literacy in increasing the innovation of Sai Silver Silver Craft SMEs in Bali in the future. This method of implementing community service begins with conducting field visits and coordinating with partners. The method of this activity is to come and provide training and discussions. The result of this activity is that the craftsmen are expected to be able to understand the importance of digital advertising by utilizing the internet, especially social media which can be accessed by more consumers by using the internet in general and social media in particular. In addition, it is also expected to help and improve welfare and innovation in developing silver handicraft products.
\end{abstract}

Keywords: MSME, Social Media, Advertising

\section{PENDAHULUAN}

Penundaan pembukaan perbatasan untuk perjalanan dari Bali ke 4.444 turis asing tentu akan memperburuk situasi UMKM di Bali. Namun justru inilah tantangan yang harus dipenuhi untuk menjadi sebuah peluang. Jika mampu mengatasinya, diyakini UMKM masih bisa bertahan. Kuncinya adalah inovasi, baik produk maupun pemasaran.

Berbagai sumber juga telah menerbitkan kajian tentang informasi tertentu mengenai dampak global COVID-19, penelitian oleh organisasi internasional dan nasional seperti UNWTO, Perserikatan Bangsa-Bangsa Organisasi Pariwisata Dunia, yang menyatakan bahwa pariwisata adalah industri yang rentan dan terburuk dalam industrinya. keberadaannya hingga saat ini. Industri ini didominasi oleh 80\% UKM dan ribuan mata pencaharian yang rentan terpengaruh, WTCC mengatakan pandemi ini dapat memotong 50 juta pekerjaan secara global di industri perjalanan dan pariwisata. Asia paling terpukul dengan sekitar 30 juta pekerja, sementara pernyataan oleh Tourism Economics mengatakan pemulihan penuh diharapkan pada 2022-2023.

Di tengah upaya pemerintah untuk meningkatkan kedatangan turis Saat bepergian ke luar negeri ke Bali, banyak pekerja di sektor pariwisata yang kehilangan pekerjaannya atau yang biasa dikenal dengan OTG (unpaid people) terus berupaya mengembangkan kreativitas dan inovasi sesuai dengan kemampuannya. Pandemi ini telah mengajarkan banyak orang untuk memperkuat engagement dan meningkatkan kreativitas Pandemi Covid 19 yang memukul rata semua lapisan masyarakat meninggalkan dampak yang cukup signifikan dari setiap aspek. Tak terkecuali aspek ekonomi. UMKM yang menjadi penyokong pertumbuhan ekonomi di Indonesia menjadi terdampak dengan adanya kebijakan baru pemerintah dan protocol kesehatan yang membuat semua serba berjauhan. 
Peraturan ini berdampak pada usaha kecil, akibatnya banyak usaha kecil bangkrut karena ketidakstabilan pendapatan dan ketersediaan modal komersial. Bagi perusahaan-perusahaan yang masih ada, seringkali mereka sudah memiliki simpanan aset, yang dapat digunakan sebagai tambalan untuk memperdagangkan modal selama masa-masa sulit. Tapi itu hanya untuk sementara. Dengan bertambahnya 4.444 data pasien COVID-19 yang terus bertambah, para pengusaha harus bermanuver membuat terobosan baru di industrinya agar bisa terus menggerakkan perekonomian. Paling terasa adalah usaha di sector wisata yang lesu. Peraturan social distancing pemerintah seakan merupakan pukulan yang berat dalam sector pariwisata. Sehingga banyak usaha di sector tersebut hibernasi untuk sementara waktu, menunggu keadaan membaik. Kerajinan perak Sai Silver yang berlokasi di Bali terletak di Jl padma no 154 Kelurahan Penatih, Denpasar Timur yang di miliki oleh Ni Putu Sari Wartini adalah satu dari usaha yang tengah bertahan, berupaya keras untuk menggerakan roda perekonomian di tengah pariwisata yang mulai lesu dan sepi.

Dari berbagai masalah yang telah dianalisa, pemasaran menjadi hal yang harus dijadikan bahan pertimbangan penting, karena pemasaran adalah ujung tombak usaha ini dalam mengenalkan produk kerajinan perak ke khlayak luas. Sai Silver sudah berupaya berupaya keras dalam hal ini, namun masih memerlukan masukan-masukan dalam kegiatan pelatihan untuk memperkaya pemahaman mereka dalam mengemas produk dalam bentuk iklan digital yang bagus dan lebih menjual. Sasaran kegiatan Pengabdian kepada masyarakat (PKM) ini adalah dengan merangkul warga masyarakat khususnya pengerajin perak Sai Silver untuk mengikuti kegiatan penyuluhan untuk meningkatkan softskill

\section{METODE PELAKSANAAN}

Metode pelaksanaan pengabdian kepada masyarakat ini diawali dengan melakukan peninjauan lapangan dan koordinasi dengan mitra. Metode kegiatan ini adalah mendatangi dan memberikan pelatihan dan diskusi Sasaran dari program ini Pengabdian Masyarakat ini adalah para pengerajin perak Sai Silver di Bali. Hari, Selasa s/d Kamis, 2, 3, dan 4 Maret 2021, Pukul 09.00 - 12.00 WITA, bertempat di UMKM Sai Silver Bali.

\section{Sai Silver}

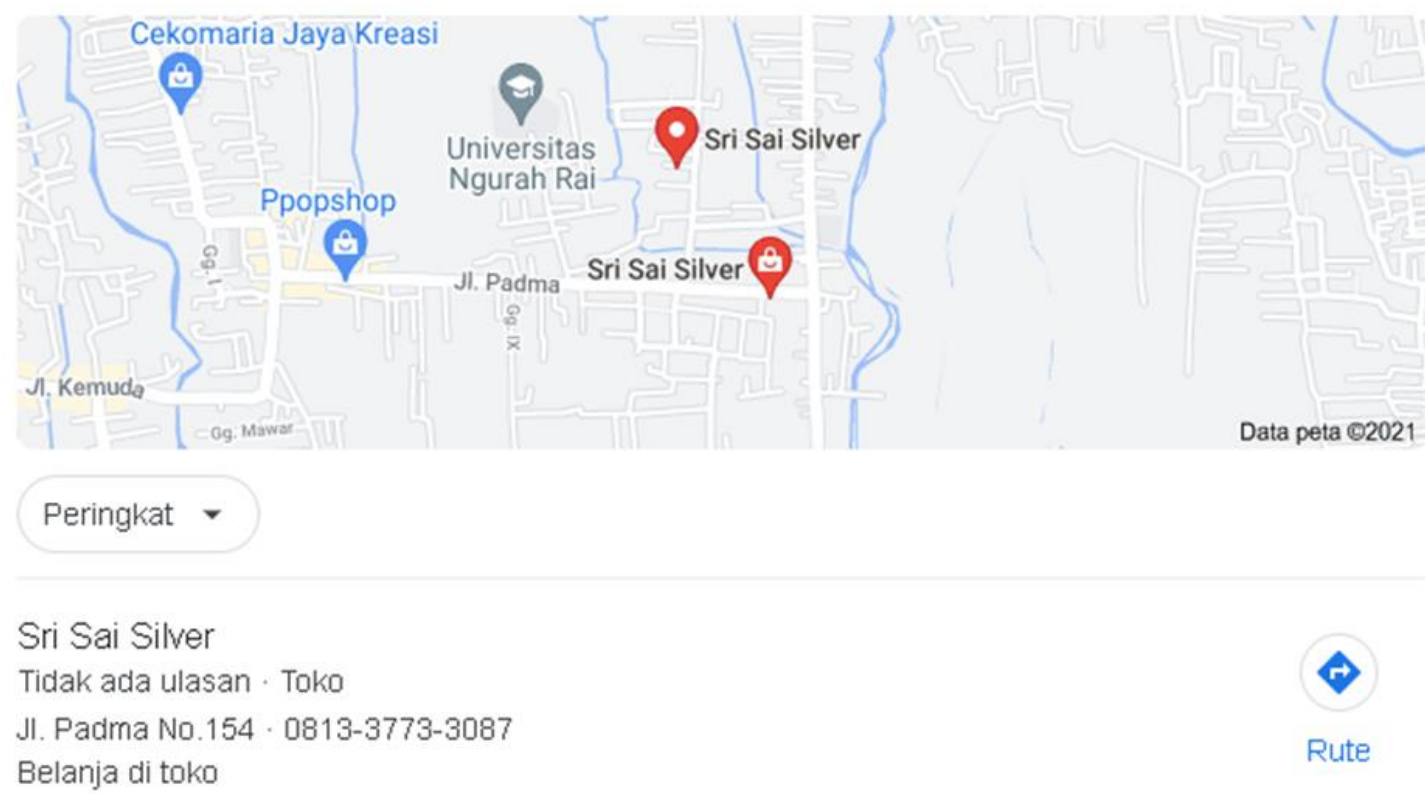

\section{HASIL DAN PEMBAHASAN}

Pandemi Covid-19 sudah menghantui Indonesia dan memberikan dampak yang luar biasa terhadap ekonomi masyarakat Indonesia sejak Maret 2020. Berbagai sektor penjualan terkena dampak negatif dari pandemi ini. Tidak sedikit mal yang harus tutup untuk mematuhi proktokol kesehatan dan tentu saja berdampak lurus dengan penjualan yang merosot. 
Ada yang gulung tikar, ada pula perusahaan yang masih tetap bisa bertahan, meski diterpa pandemi Covid-19 dan tetap menjual barang retail. Salah satu yang bisa bertahan adalah Sai Silver Bali. Dari berbagai macam daerah kerajianan perak yang ada di Indonesia, Bali merupakan salah satu tempat yang memiliki sentra kerajinan perak yang khas dan memiliki keunikan yang tidak dimiliki oleh tempat lain. Dibandingkan dengan Jogja yang memiliki HS Silver, Bali memiliki sentra kerajinan perak yang lebih beragam, Jiwa dalam masyarakata Bali terdapat jiwa seni yang tinggi dan kuat. Sudah turun temurun masyarakatnya terkenal hasil ukir ukir kerajinan tangan yang memiiki design yang menawan, unik, dan penuh seni. Di tengah perkembangan tekhnologi yang berkembang pesat. Industri perak di Bali masih mengandalkan tangan untuk proses produksinya. Sehingga mampu menjadi bangga berdaya saing dipasar dunia International karena memiliki beberapa keunggulan seperti design dan kualitas.

Perak merupakan salah satu bahan dasar untuk pembuatan berbagai perhiasan. Perak berwarna silver/abu-abu yang tidak bisa berkarat dan tahan lama. Jenis unsur dalam perak yang tergolong lembek sehingga harus dicampur dengan tembaga, kadar percampuran tembaga dan perak ini sangat berpengaruh untuk hasil penampilan perhiasan.

Kerajinan Perak Bali yang cukup khas wajib mendapatkan perhatian yang cukup serius, Sai Silver merupakan salah satu sentra kerajinan perak yang memiliki potensi untuk dikembangkan lebih besar lagi. Sai Silver membutuhkan pembinaan dan literasi mengenai pemasaran dalam dunia digital untuk mengembangkan produknya lebih luas. Literasi mengenai digital advertising (Iklan digital) sangat diperlukan untuk industri Sai Silver bertahan dan berkembang, terutama ditengah pandemic covid yang sangat berdampak pada perekonomian daerah wisata di Bali, secara tidak langsung memberikan dampak yang cukup signifikan dalam pencarian omzet kerajinan perak.

Terobosan demi terobosan harus dilakukan, salah satunya adalah dengan melakukan periklanan digital untuk memasarkan produk. Apalagi kerajinan perak tidak sama dengan barang kebutuhan pokok yang bersifat primer, kerajinan perak lebih bersifat segmented dan tidak terlalu memiliki kesempatan menjadi produk konsumsi. Terlebih lagi ditengah pandemic covid 19, minat akan prosuk kerajinan perak merosot tajam. Salah satu strategi yang bisa dilakukan adalah dengan mengembangkan lini penjualan hingga mancanegara sehingga memudahkan sentra kerajinan perak dapat bertahan.

Era digital saat ini kian mengubah wajah kehidupan manusia. Salah satu konsep pemasaran yang muncul dari adaptasi di era ini adalah digital advertising. Karakter saluran internet yang cepat dan terarah membuat komunikasi antara penjual dan pembeli justru semakin efektif dan efisien, seperti melalui browser web, halaman media sosial, blog, aplikasi dan platform lainnya di dunia maya.

Dalam Kegiatan Pengabdian Kepada Masyarakat ini hal yang menjadi sasaran utama adalah Fotografi Advertising. Karena sesuai dengan permasalahan yang dihadapi oleh Sai Silver yang menjadi lokasi penyelenggaraan kegiatan Pengabdian Kepada Masyarakat tersebut. Dengan Fotografi Advertising yang nantinya akan digitalisasi, maka diharapkan produk Sai Silver semakin dikenal dan memberikan informasi yang lebih up to date di kalangan konsumen kerajinan perak.

\section{KESIMPULAN}

Kegiatan ini menjadikan pengusaha dan para karyawan dapat mengembangkan skill dibidang fotografi untuk periklanan digital dan dapat memahami pentingnya periklanan digital dengan memanfaatkan internet khususnya sosial media yang dapat diakses oleh lebih banyak konsumen.

Selama kegiatan berlangsung peserta penyuluhan memberikan tanggapan yang sangat baik, hal ini dapat dilihat dari dukungan dan atusiasme mereka dalam setiap kegiatan yang diadakan. Dan mengikuti sesi demonstrasi fotografi dengan penuh konsentrasi serta dengan pengabdian ini dapat membuka wawasan dari para pengerajin perhiasan perak, sehingga tidak hanya memberikan tambahan pengetahuan tetapi juga meningkatkan skill dan pengenalan produk dengan menggunakan internet pada umumnya dan sosial media pada khususnya. Selain itu diharapkan juga dapat membantu dan meningkatkan kesejahteraan dan inovasi dalam mengembangkan produk kerajinan perak. 


\section{UCAPAN TERIMAKASIH}

Terimakasih kami ucapkan kepada Ni Putu Sari Wartini, selaku pemilik UMKM SAI SILVER, Bali, Dr. Wayan Ardani, S.E., M.M., selaku fasilitator, para dosen dan mahasiswa Universitas Mahendradatta, Denpasar, Bali dan Universitas Pamulang, Tangerang Selatan, Banten yang turut serta dalam kegiatan Pengabdian Kepada Masyarakat ini.

\section{DAFTAR PUSTAKA}

Ajimat, A., et al. (2020). Berwirausaha Memanfaatkan Media Sosial Pada Daerah Sepatan. ADI Pengabdian Kepada Masyarakat, 1(1), 69-76.

Ebdi, Sadjiman (2009). Nirmana Elemen- Elemen Seni dan Design. Yogyakarta: Jalasutra.

Kertamukti, Rama (2015). Strategi Kreatif dalam periklanan. Jakarta: PT Rajagrafindo Persada McQuail, Denis (2011). Teori Komunikasi Massa McQuail, Jakarta: Salemba Humanika. Nugroho, Sarwo (2015). Manajemen Warna dan Design. Yogyakarta: CV Andi Offset. Pujiyanto (2013). Iklan Layanan Masyarakat, Yogyakarta: CV Andi Offset.

Putra, IGS., et al, (2020). Dampak Pelatihan Manajemen Kreatif Industri Peci Menuju Sentra Peci Di Desa Langonsari Kecamatan Pameungpeuk Kabupaten Bandung. Coopetition: Jurnal Ilmiah Manajemen. 11(1)

Sobur, Alex (2003). Semiotika Komunikasi, Bandung: PT Remaja Rosdakarya.

Tatang (2016). Dinamika Komunikasi, Bandung: Pustaka Setia

Vera, Nawiroh (2015). Semiotika dalam Riset Komunikasi. Bogor: Ghalia Indonesia. 